\title{
Low Chronic Additions of No. 2 Fuel Oil: Chemical Behavior, Biological Impact and Recovery in a Simulated Estuarine Environment
}

\author{
Candace Oviatt, Jeffrey Frithsen, Juanita Gearing and Patrick Gearing
}

Marine Ecosystems Research Laboratory, Graduate School of Oceanography, University of Rhode Island, Kingston, Rhode Island 02881, USA

\begin{abstract}
Three long term experiments were conducted in estuarine microcosms with a water accommodated fraction of No. 2 fuel oil. The water column and benthic compartments (structure and processes) were assessed for impact of chronic oil concentrations (190 and $90 \mathrm{ppb}$ in the water column), and recovery from exposure to $90 \mathrm{ppb}$ oil concentration. Oil impacts were a function of concentration, oil residence time and temperature. The $190 \mathrm{ppb}$ concentration reduced zooplankton; both $190 \mathrm{ppb}$ and $90 \mathrm{ppb}$ reduced benthic fauna. In 1 yr after additions ceased the benthic fauna did not recover from 90 $\mathrm{ppb}$. Effects on and oil residence time in the water column were transitory; effects on and oil residence time in the benthos were long lasting. Effects on benthic fauna were most severe during the warm summer months. Hydrocarbon constitution, age, form and therefore toxicity in the estuary may or may not be equivalent to the No. 2 fuel oil used in these experiments. However, chronic water column concentrations of $100 \mathrm{ppb}$ and sediment concentrations of 500 ppm which are commonly found at the heads of estuaries indicate a potential for benthic degradation due to hydrocarbons.
\end{abstract}

\section{INTRODUCTION}

The amounts of hydrocarbons entering urban estuarine areas through sewage effluents, rivers, and drainage are larger than the amounts entering the marine environment through major spills (Van Vleet and Quinn, 1978; Hoffman et al., 1982). Most of these hydrocarbons are absorbed on particulates and, in Narragansett Bay, are derived from Number 6 fuel oil, Number 2 fuel oil and used crankcase oil (Van Vleet and Quinn, 1978). The sources appear to include oil poured down drains and runoff from roads, parking lots, and fuel-soaked soils around storage facilities (Hoffman et al., submitted). Increasing development and expansion of activity in the coastal zone and offshore waters suggest these discharges will not cease for some time.

Little is known about the quantitative responses of complex ecosystems to chronic hydrocarbon inputs. While a number of environmental inventories and assessments have been made (e. g. off-shore drilling on
Georges Bank), these are all descriptive studies that do not attempt to predict or analyze the responses of the systems to hydrocarbon discharges. The predictive models that have been developed (Mackay and Paterson, 1978) simulate acute accidental oil spills and are not applicable to the prediction of chronic effects Laboratory bioassays, although widely used, are difficult to extrapolate to natural communities because they lack complex interactions such as competition and predation (Cowell, 1974; Taub, 1976). Those charged with the responsibility for regulating and managing coastal ecosystems will need more than species lists and counts coupled with specific bioassays on which to base their decisions. 'Final judgements must always be made on the ecosystem response measured in terms of changes in populations, community interactions, diversity, stability, production and other parameters' (Cowell, 1974). In this paper 3 experiments on the effects of small chronic inputs of oil to ecosystems in marine microcosms are compared with a view towards predicting chronic hydrocarbon induced changes in urban estuarine environments. 


\section{METHODS}

\section{Microcosm Description}

Fourteen large, marine microcosms have been established outdoors at the Marine Ecosystems Research Laboratory (MERL) (Fig. 1; Pilson et al., 1979, 1980). Throughout the establishment of the microcosms, the engineering was kept simple by using as many readily

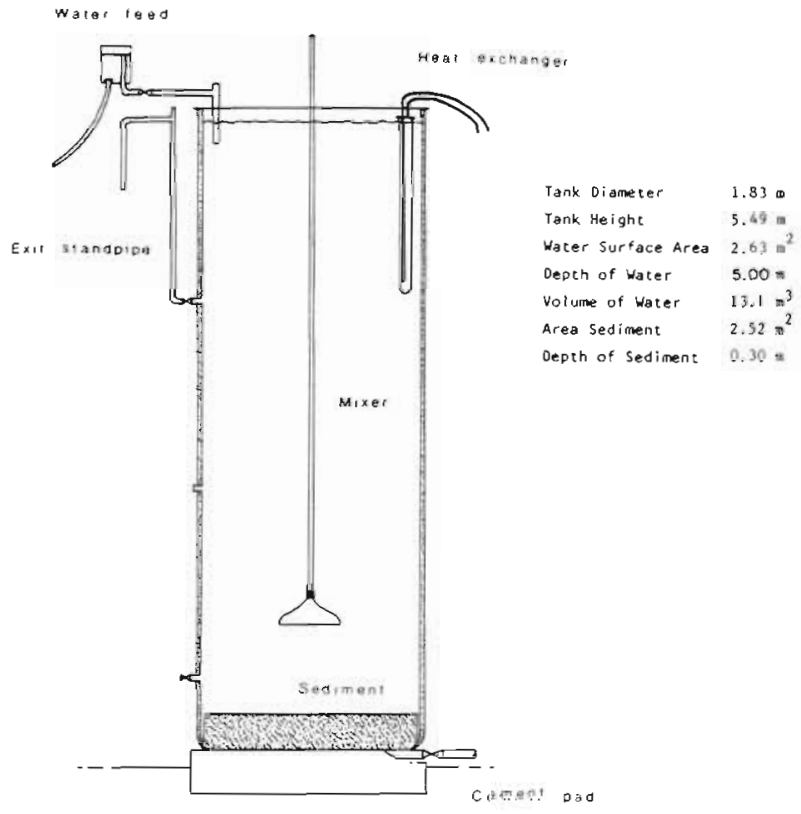

Fig. 1. Diagram of a microcosm. Temperature over annual cycle ranges from $\sim 1$ to $25^{\circ} \mathrm{C}$ and was within $\pm 2 \mathrm{C}^{\circ}$ of ambient bay water temperature. Inside walls of insulated tanks are constructed of PVC and coated with a white epoxy resin for maximum light penetration. Water height in tank is regulated by exit standpipe

available components as possible. Water from lower Narragansett Bay (Rhode Island) flows through each microcosm with a turnover time of about $30 \mathrm{~d}$ matching the water residence time in the bay (Pilson et al., 1977). During 1977 water came in slowly and continuously at a distance of $25 \mathrm{~cm}$ above the sediment. The plumbing of this delivery system allowed zooplankton to go with the faster flow to overflow drains. Since then, water has been pulsed in fast (bypassing the drains) 4 times a day at a distance of $10 \mathrm{~cm}$ below the water surface to ensure that zooplankton reach the microcosm. A vertical plunger rotating in an elliptical orbit during the mixing cycle provides turbulence to the system and resuspends bottom sediments to concentrations similar to those measured in the bay (Nixon et al., 1980a; Oviatt, 1981). The benthos, sampled by Van Veen grab from the well-studied muddy sediments in central Narragansett $\mathrm{Bay}$, is heterotrophic and interacts strongly with the water column (Phelps, 1958; Hale, 1974; Nixon et al., 1976; Nixon et al., 1980b; Pilson et al. 1980; Nixon, 1981). The large size of the microcosms permits weekly sampling of the water column for phytoplankton, zooplankton, metals, hydrocarbons, etc., and monthly sampling of the benthos for at least 20 mo. While there are important differences between the microcosms and natural systems - including problems of large animal exclusion, lack of spatial heterogeneity, and wall effects - we believe that controlled ecosystems may be used as a tool to study ecosystem functions and the effects of various environmental pollutants such as petroleum hydrocarbons.

\section{Experiments}

Three long-term experiments were conducted in the microcosms with the water accommodated fraction of No. 2 fuel oil (Table 1). During all 3 experiments, 3 microcosms were used as treatments and 3 as controls. No. 2 fuel oil was chosen because there was a lot of field data on its fate and effects with which to compare experimental results. It is transported in large volumes and frequently spilled along the northeast coast of the United States and is also a component of the chronic particulate hydrocarbon input at the urban heads of developed estuaries (Van Vleet and Quinn, 1978). Oil was added to the treated microcosms as an oil-water dispersion made by vigorous shaking (5 min of 280 motions $\min ^{-1}$ ) of one part oil $(8$ to $10 \mathrm{ml}$ ) to 1000 parts

Table 1. Outline of oil experiments

\begin{tabular}{|c|c|c|c|}
\hline Experimental detail & 1977 & $\begin{array}{l}\text { II } \\
1978\end{array}$ & $\begin{array}{l}111 \\
1978-1979\end{array}$ \\
\hline Oil addition period (d) & Feb. 14-Aug. 1 (168) & March 6-July 6 (122) & - \\
\hline Recovery period (d) & Aug. 1-Oct. 4 (64) & - & July 6-July 27 (386) \\
\hline Oil added $(g)$ & $108\left(43 \mathrm{~g} \mathrm{~m}^{-2}\right)$ & $40\left(16 \mathrm{~g} \mathrm{~m}^{-2}\right)$ & - \\
\hline Mean concentration of oil in water (ppb) & 190 & 90 & 7 \\
\hline $\begin{array}{l}\text { Percent of added oil in sediment } \\
\text { at end of experiment }\end{array}$ & - & 50 & $10-20$ \\
\hline Temperature $\left({ }^{\circ} \mathrm{C}\right)$ & $1-23$ & $0-21$ & $0-23$ \\
\hline
\end{tabular}


seawater $(8 \mathrm{l})$. The oil-water mixture was poured into an aspirator bottle and allowed to separate for $\sim 30$ min. The lower, aqueous phase was then added during the mixing cycle at a rate of $11 \mathrm{~min}^{-1}$ via Teflon tubing to a depth of $\sim 1 \mathrm{~m}$ below the water surface in the microcosms (Gearing et al., 1979). No visible slick resulted from this addition procedure. In the first experiment oil was added twice a week from February 14, 1977 to August 1, 1977 to maintain an average concentration of $190 \mathrm{ppb}$ in the water column (Table 1; Oviatt et al., 1980). During the second experiment oil was added in the same manner from March 6, 1978 to July 6,1978 to maintain an average concentration of 90 ppb. In the third experiment (July 6, 1978 to July 27 , 1979) the extent of recovery from the long term exposure to $90 \mathrm{ppb}$ was investigated.

\section{Monitoring Methods}

\section{Chlorophyll}

The fluorometric method of Holm-Hansen et al. (1965) was used to measure chlorophyll concentration weekly. Filters were normally stored wrapped in aluminum foil over desiccant in a light-tight container at $-20^{\circ} \mathrm{C}$. Storage for longer than $2 \mathrm{wk}$ was avoided. Measurements were made with a Turner Model III fluorometer.

$$
\text { Production ( } \left.{ }^{14} \mathrm{C}\right)
$$

Relative phytoplankton production was estimated by the method of Strickland and Parsons (1972). Each microcosm was sampled by collecting and pooling equal volumes of water from $0.1,2.5$ and $4.5 \mathrm{~m}$ depth weekly. The bay was sampled by collecting water from $2 \mathrm{~m}$ below the surface at the MERL pump intake. Subsamples $(50 \mathrm{ml})$ were placed into clear bottles equipped with ground glass stoppers and $1 \mu \mathrm{Ci}$ of ${ }^{14} \mathrm{C}$ labelled sodium bicarbonate was added to each. Samples from the microcosms were incubated at $0.1,0.15$, $1.0,2.5$ and $4.5 \mathrm{~m}$ for $24 \mathrm{~h}$ in their respective tanks. The bay sample was incubated in Tank 3 at the same depths and time as the tank samples. After incubation, the samples were filtered onto $25 \mathrm{~mm}$ glass fiber filters with low vacuum and the filter edges rinsed. The filters were counted on a scintillation (Beckman model LS$3510 \mathrm{~T}$ ) counter.

\section{Nutrient Chemistry}

Weekly samples from each tank (pooled over depth) and the bay $(2 \mathrm{~m})$ were used for determination of dissolved inorganic phosphate, ammonia, nitrite plus nitrate, and silicate. The samples were filtered (Millipore filters) into plastic bottles (precleaned by soaking in deionized water) using a $50 \mathrm{ml}$ plastic syringe equipped with a stainless steel or plastic filter holder. If possible, samples were analyzed the same day; if not they were stored in a freezer at $-20^{\circ} \mathrm{C}$ after filtration.

A Technicon Autoanalyzer was used for the analyses. Four channels of chemical reactions were fabricated based on the procedures recommended by Friederich and Whitledge (1972). Each sample was run in triplicate, interspersed with a synthetic seawater wash. Standards were run before the samples each day; internal standards were added at least once every 40 samples.

\section{Zooplankton}

Weekly zooplankton samples were obtained from 2 pooled vertical tows per tank, from the bottom up, taken within 20 min after mixing. One tow was taken on the light side of the tank and one on the shaded side. A \#20 plankton net with a diameter of $50 \mathrm{~cm}$ and a mesh size of $80 \mu \mathrm{m}$ was used for all samples. The pooled sample was subdivided by a zooplankton splitter. The fraction used for counts $(1 / 4)$ was preserved in buffered formalin and subsampled by Stempel pipette until 200 animals (where possible) were identified and counted. Adult copepods, copepodites, nauplii and other groups were counted. The preserved biomass fraction $\left({ }^{3} / 4\right)$ was filtered through a \#10 Nitex sieve $(153 \mu \mathrm{m})$ and washed with deionized, distilled water to remove salts and frozen immediately. The resulting sample was freeze-dried in a Virtis automatic freeze dryer and then weighed.

\section{Benthic Fauna}

The 6 microcosms were sampled monthly. Ten random cores $\left(4.16 \mathrm{~cm}^{2}\right)$ were taken monthly and sliced to 0 to 2 and 2 to $6 \mathrm{~cm}$ depth layers for the study of macrofaunal and meiofaunal abundance and composition. The coring apparatus used during the 1977 experiment consisted of a single core tube and a ball valve on the end of a long pole mounted in a rigid frame which allowed positioning of the cores within the microcosms. The same area was not sampled twice unless several months had elapsed between samples. Beginning January 1978, a flow-through coring device (5.07 $\mathrm{cm}^{2}$ ) was used so as to minimize disturbance of the loose surface flocculent layer (Frithsen et al., in press).

Individual cores were initially washed through 500 , 300 and $40 \mu \mathrm{m}$ sieves. All individuals in the top 0 to 6 $\mathrm{cm}$ retained by the 300 and $500 \mu \mathrm{m}$ sieves, except the typically meiofaunal groups such as nematodes, 
ostracods and copepods, were identified to species and counted as part of the macrofauna. Meiofauna analyses in the microcosms were performed on the same 10 monthly cores per tank taken for macrofauna analyses. To save time, all ten 0 to $2 \mathrm{~cm}$ samples from each tank were pooled giving triplicates for each treatment. For this study, meiofauna are defined as Metazoa and Foraminifera which pass through a $500 \mu \mathrm{m}$ sieve, but are retained on a $40 \mu \mathrm{m}$ sieve, except for temporary meiofauna (juvenile macrofauna) retained on the 300 $\mu \mathrm{m}$ sieve.

At the end of the experiments in 1977 and 1979, all the sediment in the $\operatorname{tank}\left(1.1 \mathrm{tank}^{-1}\right)$ was washed through $6.3 \mathrm{~mm}$ sieves ( $0.3 \mathrm{~mm}$ for the water column) and the large animals retained were enumerated and weighed.

\section{Oxygen Metabolism and Benthic Nutrient Flux}

In the 1977 experiment, benthic respiration and nutrient flux were measured monthly in samples taken by a Plexiglas box corer $\left(85.5 \mathrm{~cm}^{2}\right)$. The corer and collected core $(10 \mathrm{~cm}$ depth of sediment) were incubated in ambient temperature sea water in the laboratory for 2 to $16 \mathrm{~h}$, depending on the temperature and degree of oxygen saturation. This method of sampling resulted in considerable variability, partially because the corer often hit large oyster shells cracking the surface of the core. For the later experiments, a benthic chamber was made to fit over the entire surface of the microcosm sediments, and incubations were performed in situ.

Initial and final water samples were taken in each incubation by siphoning through a sampling hose. Oxygen was measured by Winkler titration (Strickland and Parsons, 1968). The nutrient samples were filtered through Gelman Type A glass fiber filters and preserved (ammonia: Degobbis, 1973; phosphate: Gilmartin, 1967). Ammonia was determined by the method of Solorzano (1969), nitrite-nitrate by autoanalyzer, and inorganic and dissolved organic phosphate by the method of Strickland and Parsons (1968). Oxygen and ammonia determinations were made the day the samples were taken; samples for other analyses were frozen in polyethylene bottles and analyzed later.

Occasionally during 1978 and 1979 total system metabolism and plankton metabolism were measured in Control tank 5 and Oil tank 7 by the diel curve method of Odum and Hoskin (1958) and by hanging dark and light bottles (for successive $6 \mathrm{~h}$ periods) at various depths in the tanks. Before sampling, the mixers were turned on for 15 min to mix the water column to homogeneity.

Oxygen samples were titrated within $24 \mathrm{~h}$, and calculations of total system apparent production, night respiration and phytoplankton production were made. Measurements of total system metabolism were corrected for diffusion. The rate of oxygen diffusion across the air-water interface was determined by sparging a floating Plexiglas dome with nitrogen gas and measuring the increase in oxygen concentrations over time (Nixon et al., 1980a).

\section{Hydrocarbons}

Unfiltered water samples were collected from the tanks at approximately $10 \mathrm{~cm}$ below the water surface using a manual siphon pump and solvent cleaned glass containers. Samples of oil water dispersion (OWD) were collected in glass as it was being added to the microcosms. Sediments were collected with the same corers used for benthic fauna sampling in solvent cleaned stainless steel barrels, and stored frozen in glass containers until analysis. Work-up and analysis of hydrocarbons have been performed in 3 laboratories. Detailed descriptions of individual analytical methods are given in Farrington and Tripp (1977), Gearing et al. (1978, 1979, 1980), and Wade and Quinn (1980).

Internal standards were added to all samples before extraction. Water samples were extracted by shaking with petroleum ether or methylene chloride. Experiments showed that both solvents were effective in removing the freshly added oil from the water. Samples of OWD were treated as very concentrated water samples. Sediments were extracted and saponified by refluxing with a mixture of methanolic $\mathrm{KOH}$ and benzene, with water added to prevent transesterification. The extracts were purified by thin layer (Silica gel G) and/or column chromatography (silica gel and alumina) as outlined in Gearing et al. (1978). Some samples were separated into 2 fractions during this step, the $F_{1}$ fractions containing the aliphatic and alicyclic hydrocarbons and $F_{2}$ fractions the aromatic and polyolefinic hydrocarbons. Hydrocarbons were analyzed by gas chromatography (GC) using packed FFAP, packed SP 1000 or glass capillary SE-52 columns.

\section{RESULTS AND DISCUSSION}

\section{Background Levels of Hydrocarbons}

The hydrocarbon concentrations in the water columns and sediments of the microcosms were monitored before the oil experiments from August to October 1976. Hydrocarbon concentrations in the water column of 9 microcosms averaged $7.2 \mu \mathrm{g} \mathrm{l}^{-1}$ (C. 
$\mathrm{V} .=89 \%$ ), while bay values averaged $4.4 \mu \mathrm{g} \mathrm{l}^{-1}$ (C. $\mathrm{V} .=34 \%)$. Microcosm sediments had hydrocarbon concentrations averaging $140 \mu \mathrm{g} \mathrm{g}^{-1}$ dry weight sediment $(\mathrm{C}, \mathrm{V} .=24 \%$ ), while cores taken at the bay sediment source station averaged $145 \mu \mathrm{g} \mathrm{g}^{-1}$ dry weight sediment (Gearing et al., 1980). It was concluded that there was no significant hydrocarbon contamination to the microcosms, and no differences in background hydrocarbon concentrations between individual tanks. The analytical variability for these measurements was 10 to $20 \%$ of the mean for water samples (Gearing et al., 1979) and $25 \%$ for sediment samples (Gearing et al., 1978).

\section{Description of Oil}

The oil used in these studies was a locally purchased No. 2 fuel oil, which was found to be generally similar in its chemical composition to the American Petroleum Institute standard No. 2 fuel oil. By the analytical techniques used, the $F_{1}$ hydrocarbon fraction ( $75 \%$ of the total oil) was composed of $n$-alkanes from $n$ - $C_{10}$ to $n-\mathrm{C}_{22}$, a series of isoprenoid branched compounds including norpristane, pristane, and phytane, and a chromatographically unresolved complex mixture of branched alkanes and cycloalkanes. The $\mathrm{F}_{2}$ hydrocarbon fraction ( $25 \%$ of the total) included substituted benzenes, naphthalene and its $\mathrm{C}_{1}$-through $\mathrm{C}_{5}$-substituted isomers, dibenzothiophene and $C_{1}$-dibenzothiophenes, and phenanthrene with its $C_{1}$ - to $C_{3^{-}}$ substituted isomers. The OWD used for dosing was slightly richer than the original oil in its content of the more soluble aromatic $\left(\mathrm{F}_{2}\right)$ compounds (Gearing et al., 1979), in agreement with the measured solubilities of the different species (Sutton and Calder, 1974; Mackay and Shiu, 1977). Filtration experiments with water samples from the microcosms showed that aromatics were present in dissolved form, whereas nearly all the fuel oil saturates were in microdroplets or associated with suspended solid particles (Gearing and Gearing, 1982a).

\section{Oil Behavior in the Water Column}

The concentrations of petroleum-derived hydrocarbons decreased exponentially with time following each semi-weekly addition. Thus organisms were exposed to a range of oil concentrations. During the first experiment (1977), the total hydrocarbon level varied from 300 to $500 \mu \mathrm{g} \mathrm{l}^{-1}$ just after a dosing to 30 to $70 \mu \mathrm{g} \mathrm{l}^{-1}$ immediately before the next dosing, with an overall average concentration of $190 \mu \mathrm{g} \mathrm{l}^{-1}$ (Fig. 2a). With the smaller additions in 1978 (second experiment), the concentration in the water varied from around $200 \mu \mathrm{g} \mathrm{l}^{-1}$ to 20 to $50 \mu \mathrm{g} \mathrm{l}^{-1}$ over a dosing cycle, with an overall average of $90 \mu \mathrm{g} \mathrm{l}^{-1}$ (Fig. 2b). Following the last oil addition of 1978 (third experiment, recovery from oil), the concentration of total hydrocarbons in the water declined from $149 \mu \mathrm{g} \mathrm{l}^{-1}$ with a half life of $29 \mathrm{~h}$. Within $1 \mathrm{wk}$ the water column concentrations had decreased to baseline levels, where they remained for the duration of the experiment (Gearing and Gearing, 1982a).

Removal from the water column was the overall result of several processes acting upon the oil, including evaporation, biodegradation, photo-oxidation, and sedimentation. Since experimental design did not permit the formation of surface slicks, surface wave activ-
Fig. 2. Daily concentrations of No. 2 fuel oil in water column during periods of oil addition, 1977 and 1978. Average oil concentrations were 190 and $90 \mathrm{ppb}$, for oil addition periods. Circles represent single measurements. Crosses: mean and range of values for samples taken simultaneously from more than 1 tank. See Table 1 for period of addition

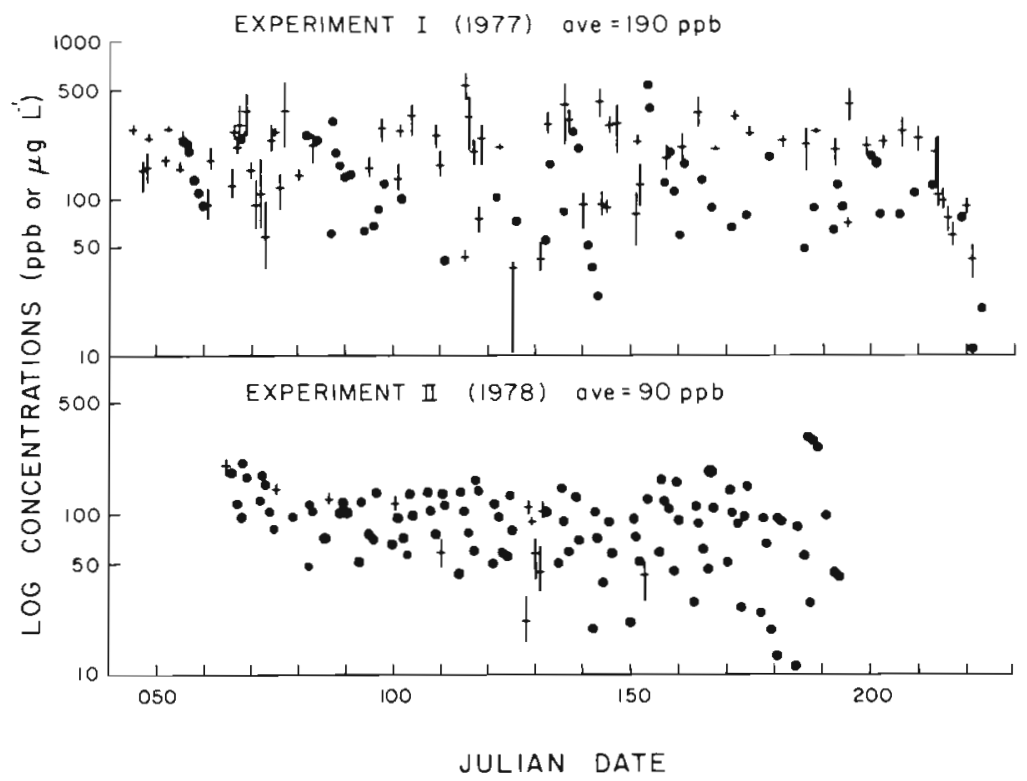


ity was not an important removal process and no attempt was made to simulate waves in the ecosystems. During the course of each experiment, the overall removal rates increased in a regular manner as the temperature increased (Fig. 3). Gearing and Gearing (1982a, b) report ancillary experiments which better define the contribution of individual processes to these
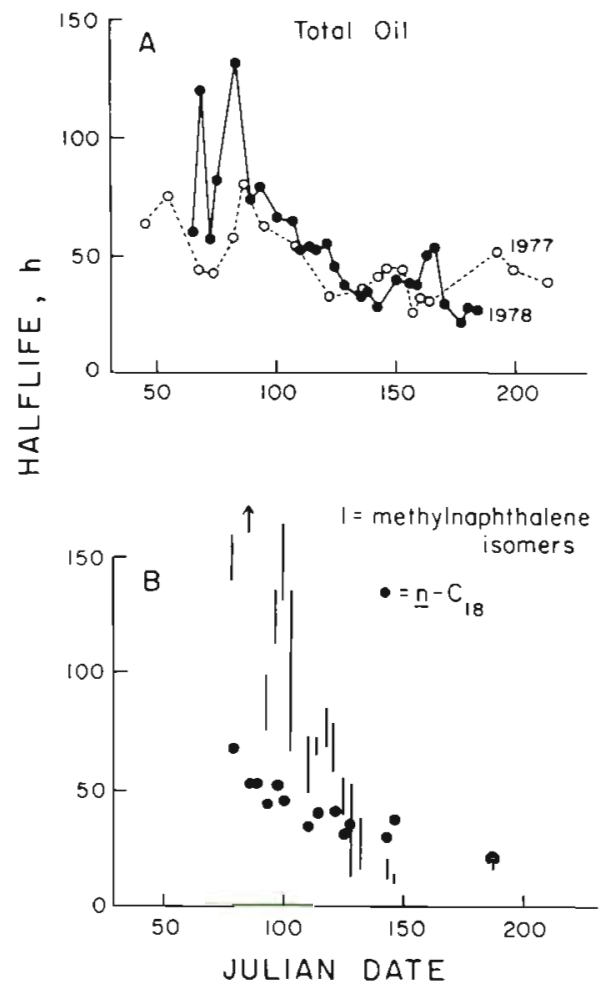

Fig. 3. Loss rates of hydrocarbons from microcosm water columns versus time. Loss rates are conveniently expressed as half lives $(=\ln 2 /$ loss rate) since the declines in concentrations were exponential $\left(C_{T}=C_{o} e^{-k T}\right.$, where $C_{T}=$ concentration at time $\mathrm{T} ; \mathrm{C}_{\mathrm{o}}=$ initial concentration; $\mathrm{k}=$ loss rate). In $\mathrm{A}$, circles indicate half lives for total hydrocarbons in Experiment I (1977, open circles) and Experiment II (1978, closed circles). B shows half lives of $\mathrm{n}-\mathrm{C}_{18}$ (solid circles) and methylnaphthalene isomers (bars: range of values) during Experiment II (1978)

removal rates. From these measurements it is clear that organisms were exposed to higher concentrations of total hydrocarbons for longer periods of time during the early winter-spring of each experiment.

Similarly, the average composition of hydrocarbons changed with time in each experiment, because the rate of removal of different hydrocarbons increased to differing extents. For instance, the half lives of $n-C_{18}$, a typical straight chain aliphatic hydrocarbon in the oil, declined in roughly the same manner as those of total hydrocarbons throughout the experiments, whereas the half lives of typical aromatic compounds (isomers of methylnaphthalene) were initially much longer and finally somewhat shorter than those of total hydrocarbons (Fig. 3B). Following the initial 1978 oil addition, the measured half lives were: total hydrocarbons, $247 h_{\text {; total }} F_{1}$ hydrocarbons, $182 h_{\text {; }}$ norpristane, $216 \mathrm{~h}$; $n-\mathrm{C}_{16}, 138 \mathrm{~h}$; total $\mathrm{F}_{2}$ hydrocarbons, $439 \mathrm{~h} ;$ and 2methylnaphthalene, $648 \mathrm{~h}$. Following the final oil addition, the half lives were 29 h, 29 h, 31 h, 19 h, 29 h, and $19 \mathrm{~h}$ respectively (Gearing and Gearing, 1982a). Gas chromatographic analyses of the hydrocarbons (Fig. 4, A-C) make the same points, showing that
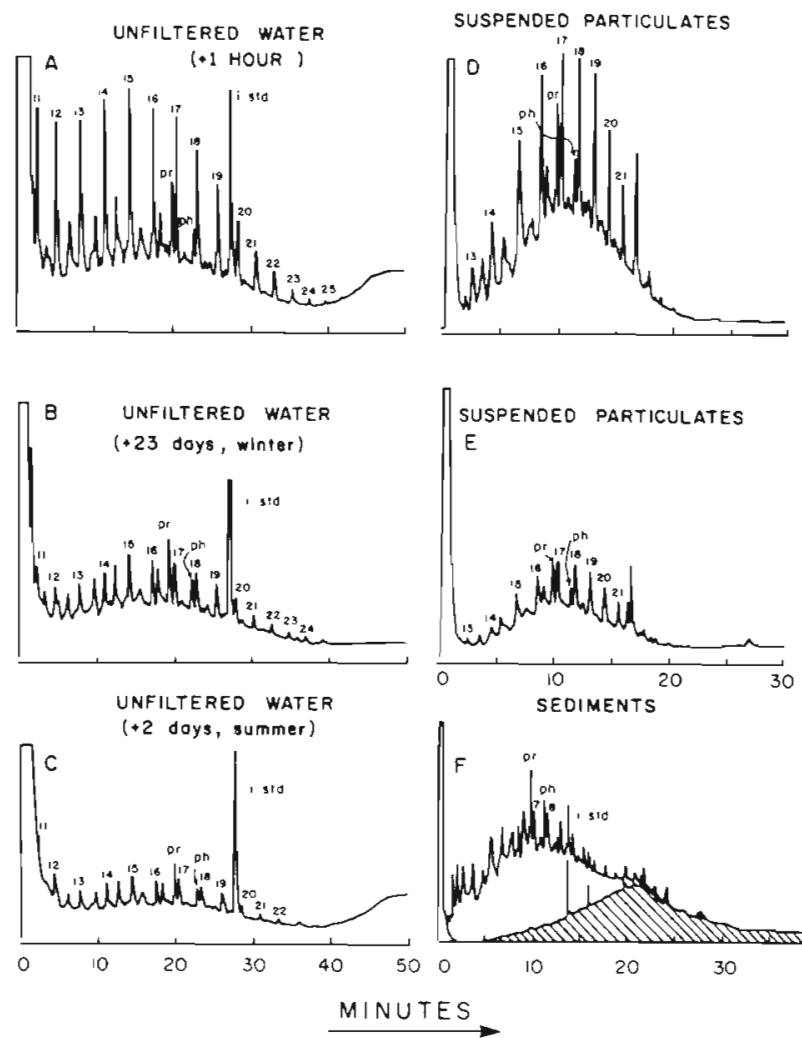

Fig. 4. Gas chromatograms (relative concentration vs. elution time) of saturated $\left(F_{1}\right)$ hydrocarbons extracted from various compartments of the microcosms. A: pattern in water column immediately after addition of oil-water dispersion. This pattern was very similar to that of hydrocarbons in the original oil. $\mathrm{B}$ and $\mathrm{C}$ show that degradative changes which occurred over $23 \mathrm{~d}$ in winter (B) took place in only $2 \mathrm{~d}$ in summer (C). D and $E$ : hydrocarbons extracted from suspended particulates on the first and second day after an oil addition. F compares degraded hydrocarbons in microcosm sediments $86 \mathrm{~d}$ after oil additions began with hydrocarbons from a control sediment (dashed area)

changes in chemical composition that required $23 \mathrm{~d}$ to occur in late winter took place in only $2 \mathrm{~d}$ in summer. Such changes in relative composition may be as important as changes in total oil concentrations when toxicity is considered, since each compound probably affects organisms differently (e. g. Anderson, 1975; Hyland and Schneider, 1976; Winters et al., 1976; King, 1977; Batterton et al., 1978). 


\section{Oil Concentrations in Sediments}

Some of the aforementioned processes effectively reduce toxicity by removing petroleum hydrocarbons. Others chemically transform the hydrocarbons into other organic compounds of unknown toxicities. Sorption to particles and sedimentation of oil, on the other hand, act to retain hydrocarbons within the ecosystem where they may affect organisms for a long time. Detailed reports of the MERL oil-sediment studies have been published (Gearing et al., 1980; Wade and Quinn, 1980).

The pattern of sedimentary oil concentrations was similar in the first and second oil experiments (Fig. 5).

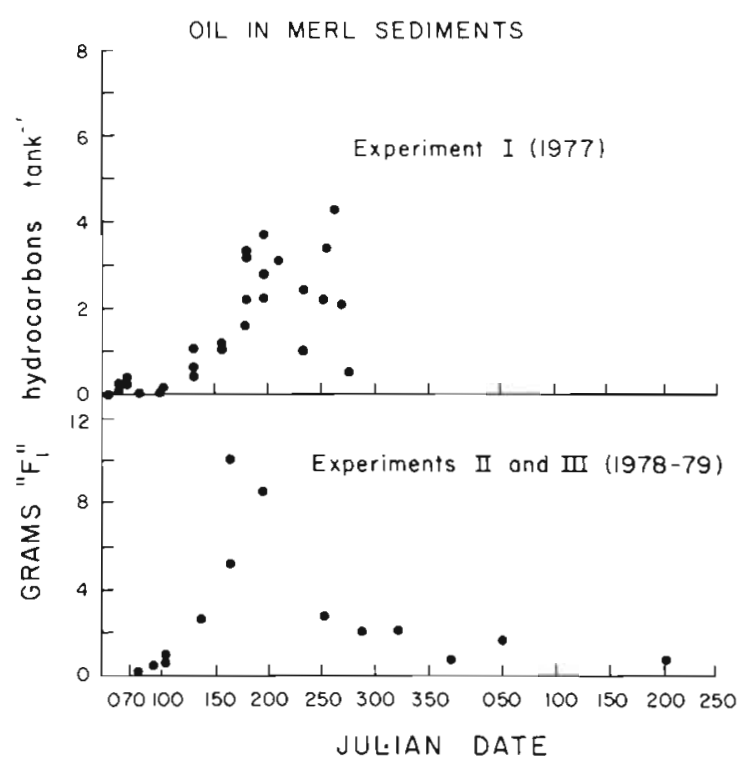

Fig. 5. Graphs of saturated $\left(F_{1}\right)$ petroleum hydrocarbons $(\mathrm{g}$ tank ${ }^{-1}$ ) found in top $\mathrm{cm}$ of sediment over time. Experiment I: $75 \mathrm{~g}$ of $F_{1}$ hydrocarbons were added to each tank between Julian days 045 and 213. Experiment II: $28 \mathrm{~g}$ were added to each tank between Days 065 and 187 of 1978 . Values corrected for background levels of hydrocarbons. Data from Gearing et al. (1980) and Wade and Quinn (1980). See Table 1 for period of addition
After a initial lag period, when relatively little oil was found in the sediment, oil concentrations increased linearly with time. Following the cessation of additions, the content of oil in the sediment declined rapidly at first, but the rate of removal decreased thereafter. A residuum of 10 to $20 \%$ of the total added oil still remained at the end of the third experiment, after 1 yr of oil recovery.

There was considerable chemical fractionation associated with sorption and sedimentation of the hydrocarbons. The saturated $\left(F_{1}\right)$ hydrocarbons associated with suspended particulate material (Fig. 4D, E) were chemically similar to $F_{1}$ hydrocarbons extracted from whole water (Figs. $4 \mathrm{~A}$ to $\mathrm{C}$ ) at the same time. Both on particles and in the sediments (Fig. 4F) there was loss of resolved compounds, particularly n-alkanes, relative to the unresolved complex mixture. The particulate material contained up to 40 to $50 \%$ of the $F_{1}$ oil added to the tanks (Gearing et al., 1980). In the surface sediments the concentration of $F_{1}$ hydrocarbons in the No. 2 fuel oil range rose from $39 \mu \mathrm{g} \mathrm{g}^{-1}$ dry wt. sediment before the second experiment to a maximum of $806 \mu \mathrm{g} \mathrm{g}^{-1}$ (which extrapolates to $47 \%$ of the added $F_{1}$ hydrocarbons) near the end of the addition period. At the end of the recovery period in 1979, approximately $12 \%$ of the added $F_{1}$ hydrocarbons (concentrations of 100 to $200 \mathrm{\mu g} \mathrm{g}^{-1}$ of primarily unresolved compounds) remained in the sediment.

Considerably less of the aromatic $\left(\mathrm{F}_{2}\right)$ hydrocarbons was found on the particulates and in the sediments, probably because of the greater water solubility of these hydrocarbons. The suspended particulates contained 3 to $21 \%$ of total $F_{2}$ hydrocarbons in the water column (Gearing et al., 1980). Sedimentary concentrations of $\mathrm{F}_{2}$ hydrocarbons in the No. 2 fuel oil range increased from a background of $6 \mu \mathrm{g} \mathrm{g}^{-1}$ to a maximum of $129 \mathrm{\mu g} \mathrm{g}^{-1}$ at the end of oil additions (about $16 \%$ of the total $F_{2}$ hydrocarbons added). At the end of the recovery period in 1979 , only 5 to $10 \%$ of the aromatic hydrocarbons could be found in the sediments. Compared to the water, the sediments were enriched in the less soluble, higher molecular weight aromatic com-

Table 2. Comparison of sedimentary oil ( $F_{1}$ hydrocarbons) with depth, 2 mo after the last oil addition in the 2 oil experiments

\begin{tabular}{|c|c|c|c|c|c|c|}
\hline \multirow[b]{2}{*}{ Depth } & \multicolumn{3}{|c|}{ October 4,1977} & \multicolumn{3}{|c|}{ September 9,1978} \\
\hline & $g \tan k^{-1}$ & $\mu \mathrm{g} \mathrm{g}^{-1} \mathrm{dry} w \mathrm{w}$ & $\begin{array}{c}\% \text { of total } \\
\text { added }\end{array}$ & $\mathrm{g} \operatorname{tank}^{-1}$ & $\mu \mathrm{g} \mathrm{g}^{-1}$ dry wt. & $\begin{array}{c}\% \text { of total } \\
\text { added }\end{array}$ \\
\hline $0-1 \mathrm{~cm}$ & 9.2 & 729 & 11.9 & 3.1 & 465 & 11.0 \\
\hline $1-2 \mathrm{~cm}$ & 6.1 & 331 & 8.0 & 1.35 & 105 & 4.8 \\
\hline $2-3 \mathrm{~cm}$ & 0.45 & 28 & 0.6 & 0 & 0 & 0 \\
\hline $3-4 \mathrm{~cm}$ & 0.17 & 9 & 0.2 & 0 & 0 & 0 \\
\hline $4-5 \mathrm{~cm}$ & 0.11 & 5 & 0.1 & 0 & 0 & 0 \\
\hline Total & 16. & & 20.8 & 4.5 & & 15.8 \\
\hline
\end{tabular}


pounds over smaller, more soluble ones (Gearing et al. 1980; Gearing and Gearing, 1982a).

The sedimentary hydrocarbon patterns were similar for both oil addition experiments, but the concentrations differed (Fig. 5), especially in relation to the total amount of oil added (cf. Gearing et al., 1979; Gearing et al., 1980; Wade and Quinn, 1980). The primary cause of the discrepancy is probably a difference in sampling efficiency of the 2 coring devices usually employed, with the flow-through corer of $1978 / 79$ being much more efficient than the ball-valve corer of 1977 (Gearing et al., 1980). A comparison of values from samples taken with similar, open-barrel corers shows that approximately the same percentage of total added $F_{k}$ hydrocarbons was found after 2 mo of recovery from both experiments (Table 2). Additional discrepancy may have arisen from analytical variablility and from the inhomogenous distribution of oil in the sediment.

\section{Oil Impact on the Ecosystem}

The long-term oil additions caused quick and dramatic changes to occur in the structure, composi- tion, and function of the experimental ecosystems. Since much of the oil $(\sim 50 \%)$ went to the benthos, the impact on benthic fauna was particularly severe and long lasting, especially at summer temperatures (Elmgren et al., 1980b; Grassle et al., 1981; Elmgren and

$$
190 \mathrm{ppb}
$$
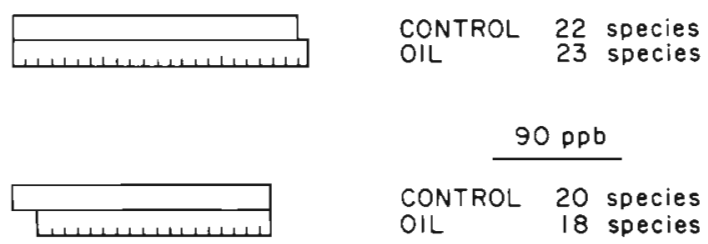

Oi) Recovery

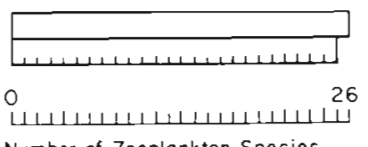

$\begin{array}{lll}\text { CONTROL } & 26 & \text { species } \\ \text { OIL } & 25 & \text { species }\end{array}$

Number of Zooplonkton Species

Fig. 6. Zooplankton species in control and oil microcosms during the 3 experiments. Each location on the horizontal axis indicates an individual species; overlapping bars: number of identical species. For time period of the 3 experiments, see Table 1

Table 3. Percentage increase or decrease of time weighted means of the oil treatment compared to the control treatment

\begin{tabular}{|c|c|c|c|}
\hline Variable & $\begin{array}{l}\text { Experiment I } \\
190 \mathrm{ppb}\end{array}$ & $\begin{array}{l}\text { Experiment II } \\
90 \mathrm{ppb}\end{array}$ & $\begin{array}{c}\text { Experiment III } \\
\text { Recovery from } 90 \mathrm{ppb}\end{array}$ \\
\hline \multicolumn{4}{|l|}{ (A) Water column } \\
\hline $\mathrm{C}-14$ & $+179 \% \cdot$ & $+37 \%$ & $+4 \%$ \\
\hline Chla & $+120 \%$ & $+67 \%$ & $+25 \%$ \\
\hline $\mathrm{NH}_{3}$ & $-77 \% \cdots$ & $-19 \%$ & $-42 \%$ \\
\hline $\mathrm{NO}_{2}+\mathrm{NO}_{3}$ & $-71 \% \cdots$ & $-63 \%$ & $-58 \%$ \\
\hline $\mathrm{PO}_{4}$ & $-14 \%$ & $-40 \%$ & $-63 \%$ \\
\hline $\mathrm{SiO}_{4}$ & $-3 \%$ & $-74 \%$ & $-63 \%$ \\
\hline Zoopl. biomass & $-43 \%$ & $-23 \%$ & $-9 \%$ \\
\hline Total zoopl. & $-78 \% \cdots$ & $-16 \%$ & $+10 \%$ \\
\hline Acartia tonsa & $+633 \% \cdots$ & $+463 \%$ & $+81 \%$ \\
\hline Acartia clausi & $-69 \%$ & $+2 \%$ & $+58 \%$ \\
\hline \multicolumn{4}{|l|}{ (B) Macrofauna } \\
\hline Total macrofauna & $-30 \%$ & $-42 \% \cdots$ & $-64 \%$ \\
\hline Mediomastus ambiseta & $-35 \%$ & $-55 \% \cdots$ & $-83 \%$ \\
\hline Nucula annulata & $-37 \%$ & $-13 \%$ & $-36 \%$ \\
\hline Yoldia limatula & $-46 \%$ & $-86 \%$ & $-89 \% \cdots$ \\
\hline Polydora ligni & $0 \%$ & $+25 \%$ & $-55 \%$ \\
\hline Ampelisca abdita & $-100 \%$ & $-93 \%$ & $-98 \%$ \\
\hline Chaetozone sp. & $+221 \%$ & $+203 \%$ & $+276 \%$ \\
\hline \multicolumn{4}{|l|}{ (C) Meiofauna } \\
\hline Total meiofauna & $-38 \% \cdots$ & $+23 \%$ & $-18 \%$ \\
\hline Nematodes & $-46 \% \cdots$ & $+9 \%$ & $-23 \%$ \\
\hline Harpacticoids & $-57 \% \cdots$ & $-35 \%$ & $+19 \%$ \\
\hline Foraminifera & $+257 \% \cdots$ & $+202 \%$ & $-14 \%$ \\
\hline Ostracods & $-100 \% \cdots$ & $-94 \% \cdots$ & $-68 \%$ \\
\hline Juvenile bivalves & $-3 \%$ & $-90 \%$ & $-37 \%$ \\
\hline Juvenile polychaetes & $+223 \%$ & $+18 \%$ & $+277 \%$ \\
\hline
\end{tabular}


A C-14 PRIMARY PRODUCTION

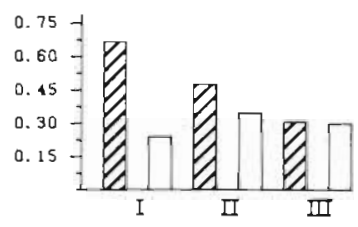

\section{E ZOOPLANKTON} BIOMASS

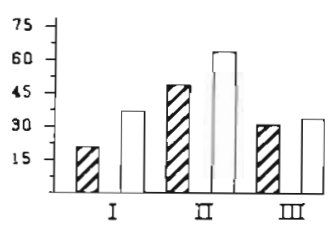

\section{BENTHIC MACROFAUNA}

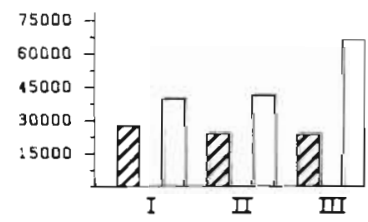

B CHLOROPHYLL a

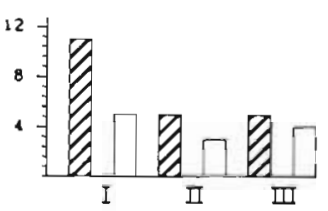

F TOTAL ZOOPLANKTON
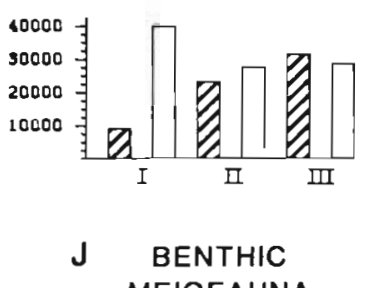
MEIOFAUNA

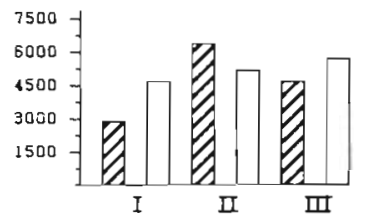

C TOTAL NITROGEN

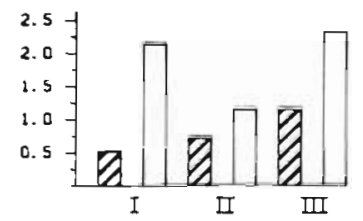

G Acartia clausi

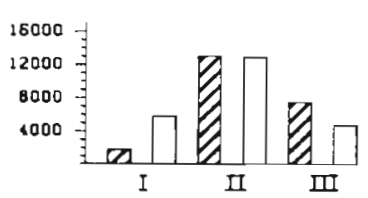

\section{K Crepidula spp. BIOMASS}

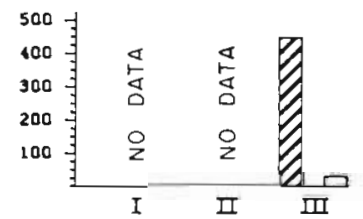

D BENTHIC RESPIRATION

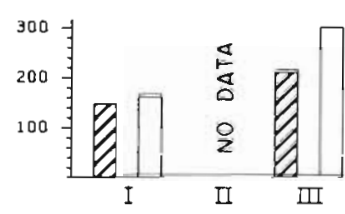

H Acartia tonsa

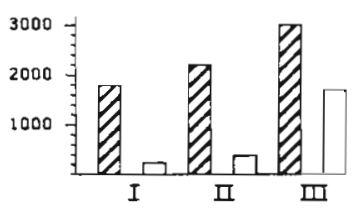

L FISH BIOMASS

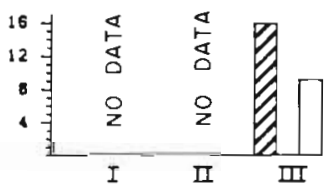

Fig. 7. Time weighted mean values for the 3 oil experiments for the period of each experiment (Table 1). Hatched bars: oil treatments; open bars: controls. (A) Primary production using ${ }^{14} \mathrm{C}_{\text {method, }} \mathrm{gCm}^{-2} \mathrm{~d}^{-1}$. (B) Chlorophyll $a$ concentration, $\mu \mathrm{g} \mathrm{l} \mathrm{l}^{-1}$. (C) Total inorganic nitrogen, $\mu \mathrm{g}$ at $\mathrm{l}^{-1}$. (D) Benthic respiration, $\mathrm{g} \mathrm{O}_{2} \mathrm{~m}^{-2} \mathrm{yr}^{-1}$. (E) Zooplankton biomass, $\mathrm{mg}$ dry wt. $\mathrm{m}^{-3}$. (F) Total zooplankton numbers, no. $\mathrm{m}^{-3}$. (G) Acartia clausi numbers, no. $\mathrm{m}^{-3}$. (H) A. tonsa numbers, no. $\mathrm{m}^{-3}$. (I) Benthic macrofauna numbers, no. $\mathrm{m}^{-2}$. (J) Benthic meiofauna numbers, no. $\mathrm{m}^{-2}$. (K) Crepidula spp. biomass, $g$ wet wt. tank ${ }^{-1}$. (L) Fish biomass, $\mathrm{g}$ wet wt. $\operatorname{tank}^{-1}$

Frithsen, 1982). Changes brought about in the water column were less dramatic and were quickly moderated after the cessation of oil additions (Elmgren et al., 1980b; Vargo, 1981). Many of the observed results would not have been predicted from single species bioassay experiments (Elmgren et al., 1980b), but have since been observed in a study of an accidental oil spill in the Baltic (Kineman et al., 1980; Elmgren and Frithsen, 1982). In no compartment of the system, i. e. phytoplankton (Vargo et al., 1982), zooplankton (Fig. 6), benthic fauna (Smith et al,, 1979), did the stress of the hydrocarbons result in decreased species diversity, leading Smith et al., (1979) to comment that changes in species composition and density are a more reliable indicator of stress.

\section{The Water Column}

The same trends were observed in the 3 oil experiments but they became more subtle with each successive experiment as the oil concentrations decreased
(Fig. 7, Table 3A). Primary production and chlorophyll tended to be higher in oil microcosms; whereas nutrients and zooplankton tended to be lower (Fig. 7. Table 3A). The increase in phytoplankton biomass, particularly diatoms (Vargo et al., 1982), and the concurrent decrease in nutrients, was thought to be due to a decreased grazing pressure caused by the reduction in the abundances of zooplankton and benthic suspension feeders (Berman and Heinle, 1980; Elmgren et al., 1980b; Vargo, 1981). The differences between treatments and controls were only occasionally statistically significant during the higher oil treatment but the trends remained during the lower oil treatment and the year of the oil recovery experiment (Table $3 \mathrm{~A}$ ). In the later experiments all variables, except phosphate and numbers of Acartia clausi, had trends consistent with the first experiment (Table 3A). Both dominant zooplankton species were apparently tolerant of oil concentrations $\leq 90 \mathrm{ppb}$ and were able to take advantage of the increased phytoplankton biomass (Fig. 7). Even at $190 \mathrm{ppb} A$. tonsa was high in one tank. At lower oil concentrations, this species did significantly better 
than in the control tanks (Table 3A). This summer species may have been exposed to lower oil concentrations than winter species since the half life of oil in the water column was much shorter during summer temperatures than during winter temperatures (Fig. 3).

In general, the value of a parameter had to differ by $69 \%$ or more before statistical significance was determined at the level of $\alpha=0.10$ or less (Table $3 \mathrm{~A}$ ). The most sensitive indicators of difference were ${ }^{14} \mathrm{C}$ production, ammonia, nitrite plus nitrate and total zooplankton during the first experiment. During the second oil experiment, the oil and control tanks differed significantly in only their concentrations of silicate and Acartia tonsa. It should be noted that $A$. tonsa was not present in any numbers, due to its seasonal periodicity, until after oil additions ceased. In the recovery experiment there were no significant differences although a difference of $81 \%$ remained for $A$. tonsa. Overall, there was slightly less variability in oil treated tanks compared to controls.

If healthy phytoplankton and zooplankton can be considered as signs of recovery, the water column of the oiled microcosms did indeed recover during the year long recovery experiment (Fig. 7). However, if recovery is measured by similarity between control

\section{A Mediomastus ambiseta}

\section{B Nucula annulata}

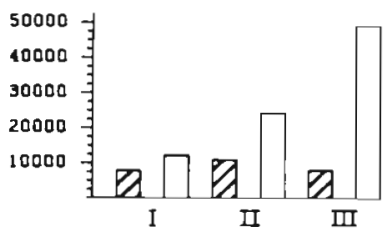

E Chaetozone sp.
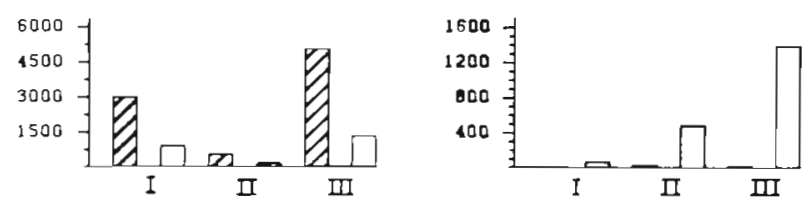

and oil tanks, there remained differences in chlorophyll, nutrients and zooplankton which followed the trends of the two oil addition experiments (Table $3 \mathrm{~A})$.

\section{The Benthos}

The abundance of benthic macrofauna was reduced in all 3 oil experiments (Fig. 8, Table 3B). Time series analyses show more clearly than these mean values that the greatest impact occurred during the summer when the animals became active (Grassle et al., 1981). The mean values are variable for individual species; however, with the exception of the small polychaete Chaetozone sp. the abundance of all species decreased. This decrease was as great during the recovery experiment as during the highest oil addition experiment (Fig. 8, Table 3B), indicating the long-term nature of the effects of No. 2 fuel oil on the benthos. There was no difference in species diversity between treatments (Smith et al., 1979), although one species, Ampelisca abdita, was completely absent during the 2 oil experiments and only minimally present during the oil recovery experiment. Field studies have also identified amphipods as a particularly sensitive macro-

\section{Yoldia limatula}

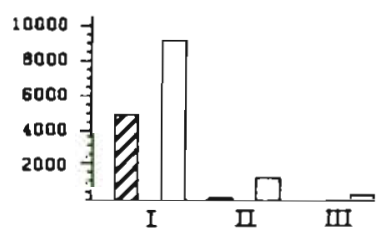

\section{G NEMATODES}

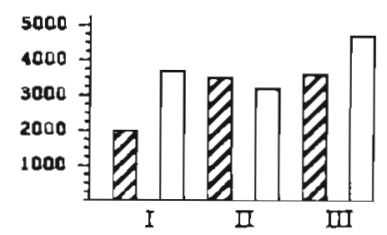

\section{Polydora ligni}

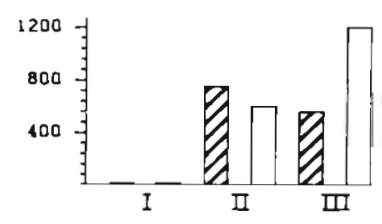

H HARPACTICOIDS

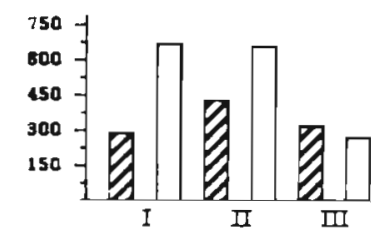

\section{FORAMINIFERA}

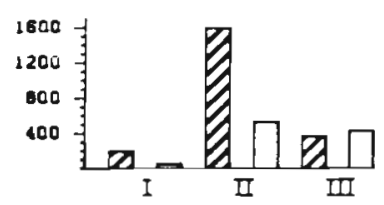

$J$ OSTRACODS

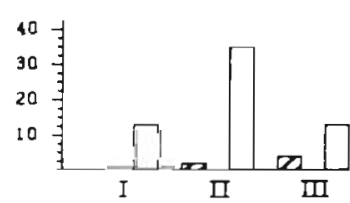

K JUVENILE BIVALVES

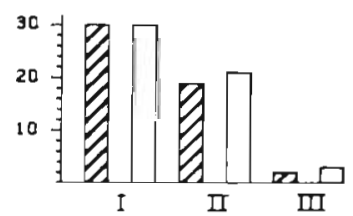

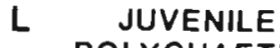
POLYCHAETES

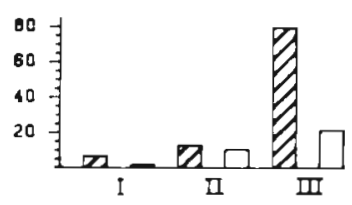

Fig. 8. Time weighted mean values $\left(\right.$ no. $\mathrm{m}^{-2}$ ) for the 3 oil experiments for the period of each experiment (Table 1). Hatched bars: oil treatments; open bars: controls. A-F: macrofauna; G-L: meiofauna 
faunal group (Bellan-Santini, 1980), specifically ampeliscid amphipods (Dauvin, 1979; Sanders et al., 1980).

The abundance of most meiofaunal groups decreased during the $190 \mathrm{ppb}$ oil experiment and during the oil recovery experiment (Fig. 8, Table 3C). Effects were less dramatic in the $90 \mathrm{ppb}$ oil experiment. As with the macrofauna, the effects of the oil on the meiofauna were long term. The most sensitive meiofaunal group was the ostracods. In both oil addition experiments, ostracods were nearly eliminated from the oiled microcosms. This result agrees well with field studies (Chasse, 1978; Elmgren et al., 1980a).

Juvenile polychaetes (temporary meiofauna) increased in abundance in the oiled microcosms during all 3 oil experiments (Table $3 \mathrm{C}$ ). They were the only benthic metazoan group to do so. Foraminifera (Elmgren et al., 1980b; Grassle et al., 1981) and benthic ciliates (Elmgren et al., 1980b) - the only protozoan groups measured - showed similar increases in abundance. The increased abundance of these 3 groups in the oiled microcosm may be due to 2 mechanisms: the reduced competition and predation pressure from organism groups more sensitive to the petroleum hydrocarbons; or an increase in food in the form of benthic bacteria capable of metabolizing petroleum hydrocarbons. Unfortunately, it is difficult to assess the magnitude of these 2 processes. Although no direct counts of benthic bacteria were made, Gearing et al. (1980) estimated that biodegradation affected the removal of 80 to $90 \%$ of the oil in the sediments.

The meiofauna were affected more quickly than the macrofauna in the first oil addition experiment. Nematodes and ostracods were both significantly lower in abundance in the oiled tanks within $33 \mathrm{~d}$ of the first oil addition, whereas no major macrofaunal group showed a significant difference between treatment until $121 \mathrm{~d}$ after the first experiment began. The earlier response of the meiofauna was most likely due to faster metabolic rates characterizing meiofaunal groups (Gerlach 1971, 1978; Coull and Bell, 1979).

\section{Other Fauna}

Greater biomass of fish was recovered from the oil microcosms $(16.8 \pm 2.2 \mathrm{~g}$ wet wt.) than from the controls $(9.2 \pm 2.7$ wet wt.) at the end of the recovery experiment (Fig. 7). In both, most were bottom feeders (little sculpin, winter flounder, cunner, tautog); 2 species (sandlaunce and pipefish) in 1 oil tank were zooplankton feeders. Also at the end of the recovery experiment, more Crepidula were found on oil tank walls than on control tank walls, although they were observed too late to obtain a quantitative sample from more than one control tank (Fig. 7). The only numerous organisms on the tank walls were Crepidula of which 6-10\% were $C$. plana and the remainder were $C$. fornicata. Using the one control tank value $(32 \mathrm{~g}$ total wet weight) there was from 6 to 20 times more Crepidula biomass on the oil tank walls $(180,471$, and $698 \mathrm{~g}$ total wet wt. Crepidula). Apparently the reduction of benthic suspension feeding organisms resulted in more food channeled to fish living in the water column and molluscs living on the tank walls. We suggest that as one part of the system, the benthos, was stressed, another part, the water column, took advantage of the increased food supply.

\section{Oxygen Metabolism and Benthic Nutrient Flux}

Benthic respiration was lower in the oil microcosms than in the control microcosms in all 3 oil experiments (Fig. 9). During the $190 \mathrm{ppb}$ oil addition experiment (I), the procedure by which respiration and nutrient flux were measured resulted in high variability and no significant differences could be shown between the oil treatment and the controls. The values were also low compared to later microcosm measurements and field measurements (Nixon et al., 1976; Nixon et al., 1980b). The in situ method of measurement used in the second and third oil experiments was more sensitive. Significantly $(\alpha=0.05)$ reduced respiration in the oil microcosms was measured during the maximum impact of the 90 ppb oil additions (June 1978). Summer measurements made during the early part of the oil recovery experiment also showed significantly reduced respiration although the difference decreased with time (Fig. 9).

During June 1978, diel partitioning of metabolism revealed no wall production or respiration occurring in the oil microcosms, although twice a week brushing

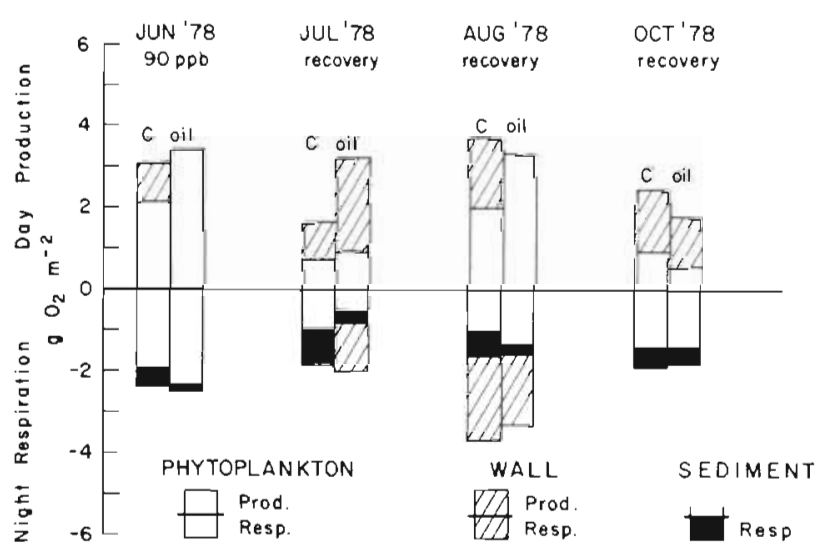

Fig. 9. Diel partitioning of metabolism in individual control (C) and treatment (oil) microcosms during second and third experiments ( $90 \mathrm{ppb}$ and recovery) 
did not remove all the epiflora and fauna in control microcosms. The oil microcosms visually appeared to have less wall growth during both addition experiments. Throughout the recovery experiment benthic respiration and nutrient flux remained lower in the oiled microcosms compared to control microcosms (Table 4). This reduced benthic remineralization of nutrients provides partial explanation for the low nutrient concentrations in the water column (Table $3 \mathrm{~A}$ ).

\section{Energy Cycling Models}

Simplified conceptual energy models of the state of the ecosystems in control microcosms, $190 \mathrm{ppb}$ oil microcosms and the $90 \mathrm{ppb}$ oil recovery microcosms summarize differences due to treatment (Fig. 10). They also illustrate the effects that would be expected in the natural ecosystem experiencing a similar impact (Elmgren and Frithsen, 1982). Carbon biomass from mean values and from biomass values at the end of Experi-
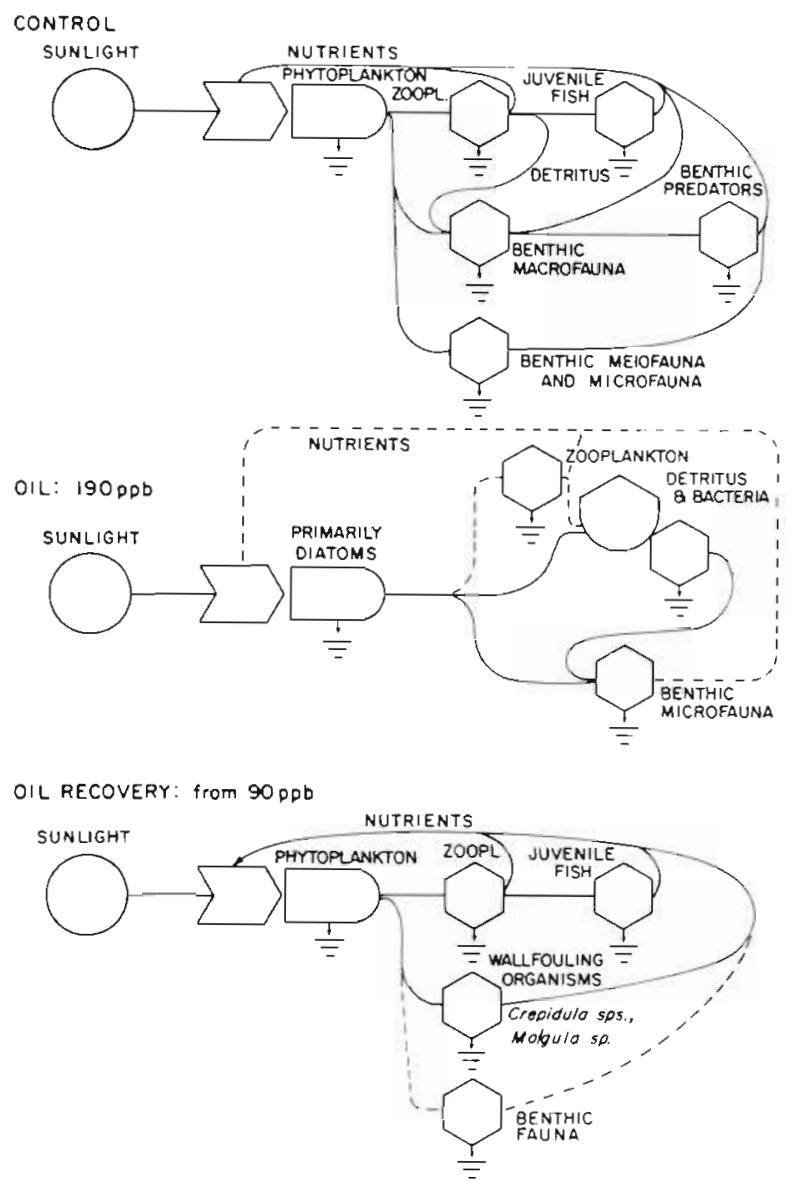

Fig. 10. Conceptual energy flow diagrams of control system, system impacted with $190 \mathrm{ppb}$ oil, and system recovering from oil. Dashed lines; weak or less than normal rates. Energy language symbols from Odum (1972)
Table 4. Integrated annual values for benthic flux during the oil recovery experiment

\begin{tabular}{|c|c|c|c|}
\hline Benthic flux & Control & $\begin{array}{l}\text { Oil } \\
\text { recovery }\end{array}$ & $\begin{array}{l}\text { As per- } \\
\text { centage } \\
\text { of control }\end{array}$ \\
\hline Oxygen $\left(\mathrm{g} \mathrm{O}_{2} \mathrm{~m}^{-2} \mathrm{yr}^{-1}\right)$ & 309 & 211 & 68 \\
\hline $\begin{array}{l}\text { Ammonia } \\
\qquad\left(\mathrm{mg}-\text { at } \mathrm{N} \mathrm{m}^{-2} \mathrm{yr}^{-1}\right)\end{array}$ & 869 & 593 & 68 \\
\hline $\begin{array}{l}\text { Nitrite + Nitrate } \\
\quad\left(\mathrm{mg}-\text { at } \mathrm{N} \mathrm{m}^{-2} \mathrm{Yr}^{-1}\right)\end{array}$ & 94 & 35 & 37 \\
\hline $\begin{array}{l}\text { Phosphorus } \\
\qquad\left(\mathrm{mg}-\text { at } \mathrm{P} \mathrm{m}^{-2} \mathrm{yr}^{-1}\right)\end{array}$ & 84 & 60 & 71 \\
\hline $\begin{array}{l}\text { Dissolved organic phosphorou } \\
\left(\mathrm{mg} \text { - at } \mathrm{P} \mathrm{m}^{-2} \mathrm{yr}^{-1}\right)\end{array}$ & 18 & 7 & 39 \\
\hline Silicate (mg - at Si $\mathrm{m}^{-2} \mathrm{yr}^{-1}$ ) & 1019 & 502 & 49 \\
\hline
\end{tabular}

ments I and III was calculated to compare compartment size within the ecosystems (Fig. 11). The treatment patterns revealed include more chlorophyll in the oil treatments compared to controls and lower values for benthic macrofauna, predators, and suspension feeders

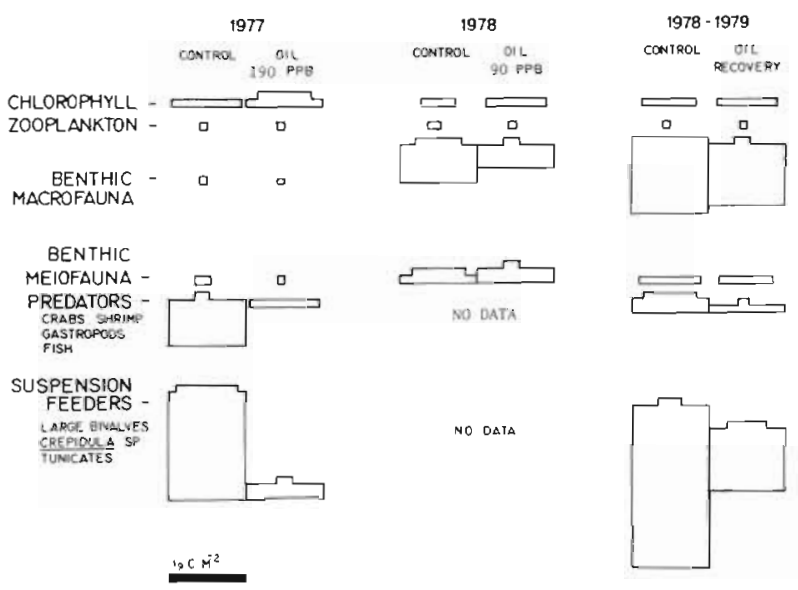

Fig. 11. Comparison of carbon in various compartments during 3 oil experiments. Chlorophyll and zooplankton carbon calculated from time weighed means. Macrofauna and meiofauna carbon calculated from last sampling before end of experiment. Benthic predators (crabs, shrimp, gastropods, fish) and suspension feeders (large bivalves, Crepidula, tunicates) were sampled when tanks were torn down and sediment sieved at end of $190 \mathrm{ppb}$ oil experiment and at end of recovery experiment. The calculation of carbon pools involved a number of assumptions: (1) $\mathrm{C}$ : $\mathrm{Chl} \mathrm{a}=30_{i}$ (2) zooplankton dry wt. $\div 2=$ zooplankton carbon; (3) one biomass measurement of $44 \times 10^{3}$ individuals $=13.24 \mathrm{~g}$ ashfree-dry wt. $(\div 2$ for $C)$ was applied to all measurements of macrofauna individuals, except 1979 oil recovery where a separate biomass estimation was made for Chaetozone based on its most probable size $\left(0.10 \mathrm{~mm}^{3}\right)$; (4) one biomass measurement of $10.4 \times 10^{6}$ individuals $=11.08 \mathrm{~g}$ wet wt. $(\times 0.2$ to give dry $w t, \div 2$ for $C$ ) was applied to all measurements of meiofauna; (5) large animals screened from end of experiments were converted to dry wt. by multiplying by 0.2 and dividing by $2.52 \mathrm{~m}^{2}$ and 2 to give $\mathrm{gC} \mathrm{m}^{-2}$, except wet weight to dry weight conversions for gastropods and large bivalves

(.1), Crangon (.17), Crepidula (.067), and tunicates (.091) 
in the oil treatments compared to controls. These treatment effects become reduced in Experiments II and III compared to Experiment I. Differences between experiments include higher control values of meiofauna and macrofauna in Experiments II and III compared to Experiment I, and correspondingly, a higher value for predators in Experiment I compared to III. In general the effect of the oil was apparent on both large and small compartments.

The chronic input of $190 \mathrm{ppb}$ of No. 2 fuel oil had a drastic effect on the system although the total amount added of $108 \mathrm{~g}$ was small. Diatoms increased as the oil reduced zooplankton and fauna which normally graze them down (Vargo et al., 1982). The reduced benthic nutrient flux may also have helped prolong diatom succession into summer when normally dinoflagellates and microflagellates appear. In the benthos Foraminifera and other ciliates increased, taking advantage of ungrazed diatoms, bacteria and fresh detritus in the surface flocculent layer as the normal grazing pressure on them by larger benthic fauna relaxed. During the 90 ppb oil additions the effects were less drastic, partly because most of the experiment was carried out in the colder months. However, the benthos was again significantly reduced by June. After 1 yr the benthos had not recovered, although the water column community fluorished and included biomasses of juvenile fish and filter feeders larger than those in control microcosms. However, just as the effects of the oil were most severe during the warmer summer months, so were rates of recovery highest. Thus if the experiment had continued another 2 or $3 \mathrm{mo}$, the return of normal benthic biomasses and function may have occurred.

\section{Perspective}

The toxicities of the components of hydrocarbons are unknown but generally No. 2 fuel oil and other refined products are more toxic than crude oil (Gordon and Prouse, 1973; Rice et al., 1976; Batterton et al., 1978). The water soluble fraction of No. 2 fuel oil may be less toxic than the less water soluble fraction, although there is controversy over the toxicity of the aromatic soluble and insoluble fractions (Rice et al., 1976; Winters et al., 1977; Batterton et al., 1978). Metabolites may be more or less toxic than parent compounds; for example, alkylation of aromatics seems to increase the toxicity of parent compounds (Rice et al., 1976). Further, hydrocarbons bound to particulates, the general form of chronic inputs from sewage effluents, may be less bioavailable and therefore less toxic than dissolved or droplet forms (Rossi, 1977). The instability of oil in water and the difficulty of accurate analyses of components lead to further uncertainty about toxic components. For these reasons we do not know what components of the No. 2 fuel oil led to the impacts observed in these experiments and we must be cautious about extrapolating from these results to field situations where the hydrocarbons are not No. 2 fuel oil. However, along the Northeast coast of the United States No. 2 fuel oil is the main type of hydrocarbon transported and it is often spilled and it is a component of the hydrocarbons which enter the heads of estuaries.

At the heads of estuaries a variety of anthropogenically derived pollutants enter the water from rivers, land runoff, and sewage treatment plant effluents. These pollutants include hydrocarbons, nutrients, metals and toxic organic compounds. Field studies revealing lowered environmental quality and depressed biota have not revealed the causative substance (Widdows et al., 1980-81). The microcosm results, however, have shown that chronic water column concentrations of No. 2 fuel oil greater than $100 \mathrm{ppb}$ and surface sediment concentrations of $500 \mathrm{ppm}$ alone will cause long lasting environmental damage. Hydrocarbon concentrations of these magnitudes may not be so toxic if the hydrocarbons are not No. 2 fuel oil or the oils are very weathered or tightly bound to particles. These levels of concentration should, however, pose an alert for potential damage. They are levels that are commonly measured in the water columns of urban water fronts and in the surface flocculent layer of sediment. In Narragansett Bay sediment, concentrations of this magnitude occur almost halfway down the estuary (Van Vleet and Quinn, 1978).

\section{SUMMARY}

(1) The No. 2 fuel oil in these experiments was $25 \%$ aromatic dissolved in the water of the microcosms and $75 \%$ saturates in micro-droplets or associated with suspended solid particles in the water column.

(2) The concentrations of oil in the water decreased exponentially with time after each addition with half lives decreasing from days to hours from winter to summer temperatures.

(3) About $50 \%$ of the added oil went to the surface flocculent layer of the sediment. As it became incorporated into the sediments its degradation rate became slow and 10 to $20 \%$ of the oil reaching the sediment was still present $1 \mathrm{yr}$ after additions had ceased.

(4) Oil concentrations of $190 \mathrm{ppb}$ in Experiment I reduced zooplankton in the water column; water column effects were slight at oil concentrations of $90 \mathrm{ppb}$ in Experiment II. During the oil recovery Experiment III, oil concentrations quickly declined to background levels and there were no detrimental impacts due to oil on the water column. 
(5) Oil impacts on benthic fauna were severe and long lasting; 1 yr after the cessation of oil additions the benthos had not recovered. Benthic respiration and nutrient flux were reduced during this year in the oiled microcosms compared to the controls.

(6) Indirect effects of the oil included increased phytoplankton and benthic diatoms, and increased numbers of Foraminifera and the polychaete Chaetozone sp. These increases probably resulted from reduced grazing pressure from oil impacted species. Another indirect effect was enhanced productivity of the water column during the oil recovery experiment. This component of the system seemed to take advantage of the reduced benthic activity by utilizing a greater portion of the primary productivity than occurred in the control microcosms.

(7) While the toxic components of hydrocarbons are difficult to define and analyze, these microcosm results suggest that benthic fauna in estuaries receiving chronic hydrocarbon additions may be degraded due to these hydrocarbons even when the water column appears particularly productive.

Acknowledgements. As with all our microcosm experiments, many people participated in this study. The experiment was conducted under the direction of Michael E. Q. Pilson. Individual responsibilities were as follows: Gabriel Vargo - phytoplankton and nutrients; Sandra Vargo and Donald Heinlezooplankton; Ragnar Elmgren and David Rudnick - benthic meiofauna; J. Frederick Grassle and Judith Grassle - benthic macrofauna; Scott Nixon, David Rudnick and John Kelly benthic respiration and nutrient fluxes; John Farrington and James Quinn - hydrocarbons; Jerry Mearns, Eric Anderson and Aimee Keller, data management. This work was supported by EPA grants \#R803902020, \#806072010 and \# 806072020 .

\section{LITERATURE CITED}

Anderson, J. W. (1975). Laboratory studies on the effects of oil on marine organisms: an overview. American Petroleum Institute, Washington, D.C., Publ. No. 4249

Batterton, J. C., Winters, K., Van Baalen, C. (1978). Sensitivity of three microalgae to crude oils and fuel oil. Mar. environ. Res. 1: 31-41

Bellan-Santini, D. (1980). Relationship between populations of amphipods and pollution. Mar. Pollut. Bull. 11:224-227

Berman, M., Heinle, D. R. (1980). Modification of feeding behavior of marine copepods by sublethal concentrations of water-accommodated fuel oil. Mar. Biol. 56: 59-64

Chasse, C. (1978). The ecological impact on and near shores by the Amoco Cadiz oil spill. Mar. Pollut. Bull. 9: 298-301

Coull, B. C., Bell, S. S. (1979). Perspectives of marine meiofaunal ecology. In: Livingston, R. J. (ed.) Ecological processes in coastal marine systems. Marine Science, Vol 10. Plenum. Press, New York, pp. 189-216

Cowell, E. B. (1974). A critical examination of present practice. In: Beynan, L. R., Cowell, E. B. (eds.) Ecological aspects of toxicity testing of oils and dispersants. Wiley, New York, pp. 97-104

Dauvin, J. C. (1979). Impact des hydrocarbuies De l'Amoco Cadiz sur le peuplement infralittoral des sables fins de la
Pierre Noire (Baie De Morlaix) J. Rech. Oceanogr. 4: $28-29$

Degobbis, D. (1973). On the storage of seawater samples for ammonia determination. Limnol. Oceanogr. 18: 146-150

Elmgren, R., Frithsen, J. B. (1982). The use of experimental ecosystems for evaluating the environmental impact of pollutants: a comparison of an oil spill in the Baltic Sea and two long-term, low-level oil addition experiments in mesocosms. In: Grice, G. D., Reeve, M. (eds.) Marine mesocosms: biological and chemical research in experimental ecosystems. Springer-Verlag, New York, pp. $153-165$

Elmgren, R., Hansson, S., Larsson, U., Sundelin, B. (1980a). Impact of oil on deep soft bottoms. In: Kineman, J. J., Elmgren, R., Hansson, S. (eds.) The Tsesis oil spill: report of the first year scientific study (Oct. 26, 1977 to Dec. 1978). US Dept. of Commerce, Office of Marine Pollution Assessment, NOAA, Boulder, Colorado, USA, pp. 97-126 Elmgren, R., Vargo, G. A., Grassle, J. F., Grassle, J. P., Heinle, D. R., Langlois, G., Vargo, S. L. (1980b). Trophic interactions in experimental ecosystems perturbed by oil. In: Geisy, J. P. (ed.) Microcosms in ecological research, DOE symposium series, Augusta, GA, November 8-10, 1978. Conf. 781101, National Technical Information Service, pp. $779-800$

Farrington, J. W., Tripp, B. W. (1977). Hydrocarbons in westem North Atlantic surface sediments. Geochim. cosmochim. Acta 41: 1627-1641

Friederich, G. O., Whitledge, T. (1972). Autoanalyzer procedures for nutrients. In: Pavlou, S. D. (ed.) Chemostat methodology and chemical analyses. Spec. Rep. 52. Dept. Oceanogr. Univ. of Wash., Seattle, pp. 38-60

Frithsen, J. B., Rudnick, D. T., Elmgren, R. (in press). A new, flow-through corer for the quantitative sampling of surface sediments. Hydriobiologia

Gearing, J. N., Gearing, P. J. (submitted). Effects of suspended load and solubility on sedimentation of petroleum hydrocarbons in controlled estuarine ecosystems. Can. J. Fish. Aquat. Sci.

Gearing, J. N., Gearing, P. J., Lytle, T. F., Lytle, J. S. (1978). Comparison of thin-layer and column chromatography for separation of sedimentary hydrocarbons. Analyt. Chem. 50: $1833-1836$

Gearing, J. N., Gearing, P. J., Wade, T., Quinn, J. G., McCarty, H. B., Farrington, J., Lee, R. F. (1979). The rates of transport and fates of petroleum hydrocarbons in a controlled marine ecosystem and a note on analytical variability. In: Proceedings of the 1979 oil spill conference (prevention, behavior, control, cleanup). American Petroleum Institute, Washington, DC, Publ. No. 4308, pp. $555-564$

Gearing, P. J., Gearing, J. N. (1982a). Behavior of no. 2 fuel oil in the water column of controlled ecosystems. Mar. environ. Res. 6: 115-132

Gearing, P. J., Gearing, J. N. (1982b). Transport of No. 2 fuel oil between water column, surface microlayer, and atmosphere in controlled ecosystems. Mar. environ. Res. 6: 133-142

Gearing, P. J., Gearing, J. N., Pruell, R. J., Wade, T. L., Quinn, J. G. (1980). Partitioning of No. 2 fuel oil in controlled estuarine ecosystems. Sediments and suspended particulate matter. Environ. Sci. Technol. 14: 1129-1136

Gerlach, S. A. (1971). On the importance of marine meiofauna for benthos communities. Oecologia 6: 176-190

Gerlach, S. A. (1978). Food-chain relationships in subtidal silty sand marine sediments and the role of meiofauna in stimulating bacterial productivity. Oecologia 33: 55-69 
Gilmartin, M. (1967). Changes in inorganic phosphate concentrations occurring during sea water sample storage. Limnol. Oceanogr. 12: 325-328

Gordon, D. C., Prouse, N. J. (1973). The effects of three oils on marine phytoplankton photosynthesis. Mar. Biol. 22: 329-333

Grassle, J. F., Elmgren, R., Grassle, J. P. (1981). Response of benthic communities in MERL experimental ecosystems to low level, chronic additions of \# 2 fuel oil. Mar. environ. Res. 4: 279-297

Hale, S. S. (1974). The role of benthic communities in the nutrient cycles of Narragansett Bay, MS thesis, University of Rhode Island, Kingston, Rhode Island

Hoffman, E. J., Mills, G. L., Latimer, L. S., Quinn, J. G. (1982). Annual fluxes of petroleum hydrocarbons to the coastal environment via urban runoff. Can. J. Fish. Aquat. Sci. (in press)

Hoffman, E. J., Latimer, J. S., Quinn, J. G. (submitted). Petroleum hydrocarbons in urban runoff from commercial land use area. J. Wat. Pollut. Control Fed

Holm-Hansen, O., Lorenzen, C. T., Holmes, R. W., Strickland, J. D. H. (1965). Fluorometric determination of chlorophyll. J. Cons. perm, int. Explor. Mer 30: 3-15

Hyland, J. L., Schneider, E. D. (1976). Petroleum hydrocarbons and their effects on marine organisms, populations, communities and ecosystems. In: Sources, effects and sinks of hydrocarbons in the aquatic evironment. Amer. Inst. Biol. Sci., Washington, DC, pp. 464-506

Kineman, J. J., Elmgren, R., Hansson, S. (eds.) (1980). The Tsesis oil spill. Report of the first year scientific study (Oct. 26, 1977 to Dec. 1978), U.S. Dept. of Commerce, Office of Marine Pollution Assessment, NOAA, Boulder, Colorado, USA

King, P. J. (1977). An assessment of the potential carcinogenic hazard of petroleum hydrocarbons in the marine environment. Rapp. P.-v. Réun. Cons. int. Explor. Mer 171: 202-211

Mackay, D., Paterson, S. (eds.) (1978). Oil spill modelling. Proceedings of a workshop. Publication EE-12, Institute for Environmental Studies, University of Toronto, Toronto, Ontario, Canada MSS 1A4, pp. 1-199

Mackay, D., Shiu, W. Y. (1977). Aqueous solubility of polynuclear aromatic hydrocarbons. J. Chem. Eng. Data 22: 399-402

Nixon, S. W. (1981). Remineralization and nutrient cycling in coastal marine systems. In: Neilson, B. J., Cronin, L. E. (eds.) Estuaries and nutrients. Numana Press, New Jersey, pp. 111-138

Nixon, S. W., Alonso, D., Pilson, M. E. Q., Buckley, B. A. (1980a). Turbulent mixing in aquatic microcosms. In: Giesy, J. P. (ed.) Microcosms in ecological research. DOE Symposium Series, Augusta, Ga. November 8-10, 1978, Conf. 781101. National Technical Information Service، pp. 818-849

Nixon, S. W., Kelly, J. R., Furnas, B. N., Oviatt, C. A., Hale, S. S. (1980b). Phosphorus regeneration and the metabolism of coastal marine bottom communities. In: Tenore, K. Coull, B. (eds.) Marine benthic dynamics. University of South Carolina Press, Columbia, S. C., pp. 219-242

Nixon, S. W., Oviatt, C. A., Hale, S. S. (1976). Nitrogen regeneration and the metabolism of coastal marine bottom communities. In: Anderson, J. M., MacFaden, A. (eds.) The role of terrestrial and aquatic organisms in decomposition processes. The 17 th Symposium of the British Ecological Society 15-18 April 1975, pp. 269-283

Odum, H. T. (1972). An energy circuit language for ecological and social systems: its physical basis. In: Patten, B. C. (ed.)
Systems analysis and simulation in ecology, Vol. II. New York Academic Press, New York, pp. 140-212

Odum, H. T., Hoskin, C. M. (1958). Comparative studies on metabolism of marine waters. Publs Inst. mar. Sci. Univ. Tex. 5: $16-46$

Oviatt, C. A. (1981). Effects of different mixing schedules on phytoplankton, zooplankton and nutrients in marine microcosms. Mar. Ecol. Prog. Ser. 4: 57-67

Oviatt, C. A., Walker, H., Pilson, M. E. Q. (1980). An exploratory analysis of microcosm and ecosystem behavior using multivariate techniques. Mar. Ecol. Prog. Ser. 2: 179-191

Phelps, D. K. (1958). A quantitative study of the infauna of Narragansett Bay in relation to certain physical and chemical aspects of their environment. M. S. thesis, University of Rhode Island, Kingston, R. I.

Pilson, M. E. Q., Oviatt, C. A., Nixon, S. W. (1980). Annual nutrient cycles in a marine microscosm. In: Giesy, J. P. (ed.) Microcosms in ecological research. DOE Symposium Series, Augusta Ga. November 8-10, 1978, CONF. 781101, National Technical Information Service, pp. 753-778

Pilson, M. E. Q., Oviatt, C. A., Vargo, G. A., Vargo, S. L. (1979). Replicability of MERL microcosms: initial observations. In: Jacoff, F. S. (ed.) Advances in marine evironmental research. Proc. of a Symp., June, 1977. EPA-600/9-79035. Environmental Protection Agency, Narragansett, Rhode Island, pp. 359-381

Pilson, M. E. Q., Vargo, G. A., Gearing, P., Gearing, J. N. (1977). The marine ecosystems research laboratory; a facility for the investigation of effects and fates of pollutants. In: Energy/environment Proc. 2nd National Conf., Interagency R \& D Program, EPA - 600/9-77-012. Environmental Protection Agency, Washington, D. C. 6-7 June 1977, pp. $513-516$

Rice, S. D., Short, J. W., Darmin, J. F. (1976). Comparative oil toxicity and comparative animal sensitivity. In: Wolfe, D. A. (ed.) Fate and effects of petroleum hydrocarbons in marine ecosystems and organisms. Proceedings of a Symposium. Pergamon Press, New York, pp. 78-94

Rossi, S. S. (1977). Bioavailability of petroleum hydrocarbons from water, sediments, and detritus to the marine annelid Neanthes arenaceodentata. In: Proceedings 1977 oil spill conference (Prevention, behavior, control, cleanup) API Pub. No. 4284, pp. 621-625

Sanders, H. L., Grassle, J. F., Hampson, G. R., Morse, L. S., Garner-Price, S., Jones, C. C. (1980). Anatomy of an oil spill: long-term effects from the grounding of the barge Florida off West Falmouth, Massachusetts. J. mar. Res. 38 (2): $265-380$

Smith, W., Gibson, V. R., Brown-Leger, L. S., Grassle, J. F. (1979). Diversity as an indicator of pollution: cautionary results from microcosm experiments. In: Grassle, J. F., Patel, G. P., Smith, W. K., Taillie, C. (eds.) Ecological diversity in theory and practice. International Cooperative Publishing House, Fairland, Maryland, pp. 269-277

Solorzano L. (1969). Determination of ammonia in natural waters by phenolhypochlorite method. Limnol. Oceanogr. 14: 799-801

Strickland, J. D. H., Parsons, T. R. (1968). A practical handbook of seawater analysis. Bull. Fish. Res. Bd Can. 167: $1-311$

Strickland, J. D. H., Parsons, T. R. (1972). A practical handbook of seawater analysis. Bull. Fish. Res. Bd Can. 169: $1-310$

Sutton, C., Calder, J. A. (1974). Solubility of higher-molecular - weight $-n$ - paraffins in distilled water and seawater. Environ. Sci. Technol. 8: 654-657 
Taub, F. B. (1976). Demonstration of pollution effects in aquatic microcosms. Intern. J. environ. Stud. 10: 23-33

Van Vleet, E. S., Quinn, J. G. (1978). Contribution of chronic petroleum inputs to Narragansett Bay and Rhode Island Sound sediments. J. Fish. Res. Bd Can. 35: 536-543

Vargo, S. L. (1981). The effects of chronic low concentrations of No. 2 fuel oil on the physiology of a temperate estuarine zooplankton community in the MERL microcosms. In: Vernberg, F. T., Calabrese, A., Thurberg, F. P., Vernberg, W. B., (eds.) Pollution and physiology of marine organisms. Academic Press, New York, pp. 295-322

Vargo, G., Hutchins, M., Almquist, G. (1982). The effect of low, chronic levels of No. 2 fuel oil on natural phytoplankton assemblages in microcosms. I. Species composition and seasonal succession. Mar. environ. Res. 6 (3): in press

Wade, T. L., Quinn, J. G. (1980). Incorporation, distribution and fate of saturated petroleum hydrocarbons in sediments from a controlled marine ecosystem. Mar. environ. Res. 3: 15-33

Widdows, J., Phelps, D. K., Galloway, W. (1980-81). Measurement of physiological condition of mussels transplanted along a pollution gradient in Narragansett Bay. Mar. environ. Res. 4: 181-194

Winters, K., O'Donnell, R., Batterton, J. C., Van Baalen, C. (1976). Water soluble components of four fuel oils: chemical characterization and effect on growth of microalgae. Mar. Biol. 36; 269-276

Winters, K., Van Baalen, C., Nicol, J. A. C. (1977). Water soluble extractives from petroleum oils: chemical characterizations and effects on microalgae and marine animals. Rapp. P.-v. Réun. Cons. int. Explor. Mer 171: 166-174

This paper was submitted to the editor; it was accepted for printing on April 29, 1982 